\title{
Effects of parity and disorders of the periparturient period in cows upon biochemical and immunological parameters in newborn calves
}

\author{
R. Skrzypek \\ Department of Cattle Breeding, Agricultural University of Poznan \\ Wolyńska 33, 60-637 Poznań. Poland
}

(Received 6 Febrauary 1991; accepted 14 December 1992)

\begin{abstract}
The study was carried out on 166 single-born sucking calves of the Lowland Black-and-White breed and crosses of this breed with Holstein-Friesian. Samples were taken from calves at the age of 1 day ( $24 \pm 6$ hours) and 5 days ( \pm 1 day). The blood components assayed were: glucose, bilirubin, cholesterol, GOT, GPT, total protein, albumins, and alpha-, beta- and gammaglobulins.

Statistical analysis of data showed that parity and periparturient disorders in cows had a significant influence on blood composition and mortality rate in calves. Calves born from second parity cows had the most advantageous blood composition, revealing the highest level of glucose and cholesterol, whereas in calves born from older cows these constituents showed the lowest values.

Calves derived from cows with periparturient disorders had decreased glucose, total protein, betaand gammaglobulins levels. Dystocia and milk fever had the most unfavourable effects on the biochemical and immunological status of calves.
\end{abstract}

KEY WORDS: sucking calves, dam disorders, blood composition

INTRODUCTION

Reduction of health problems in newborn calves still remains of great importance. Roy (1990) reported that even under very good environmental conditions, losses of calves during the first month after birth reached $6.5-8.5$ per cent.

Epidemiological studies have shown that parity and periparturient disorders in the dam have an essential effect on calf mortality (Chmielnik and Sawa, 1988; Żarnecki et al., 1988; Skrzypek et al., in print). However, the biological mechanisms underlying those relationships require further studies.

The aim of the present work was to determine the effects of parity and 
periparturient disorders in dams on the basic blood diagnostic parameters in sucking calves, and to highlight the biochemical and immunological backgrounds of these influences on the newborn.

\section{MATERIAL AND METHODS}

The investigations were carried out on the University farm Dlon on 166 single-born calves of the Lowland Black-and-White breed and crosses of this breed with Holstein-Friesian, which survived the first five days after birth. The group was composed of 67 heifers and 99 bulls. The disorders of the periparturient period in dams were classified as follows:

1. Placenta retention $(n=23)-$ if placenta was not separated from the uterus within 12 hours after delivery of the calf.

2. Dystocia $(n=9)-$ if delivery required the assistance of at least 2 persons or veterinary intervention.

3. Milk fever $(n=7)-$ if a cows's recovery to normal motor functions required veterinary intervention.

The remaining deliveries were considered normal $(n=127)$.

For the first 5 days after birth the calves were kept with their dams in separate pair-pens. The cows were tied while the calves had free access to them, sucking colostrum to appetite. In the cases of milk fever, the calves were kept with other dams which had calved approximately at the same period as their own dams.

Samples were taken twice from calves by venipuncture at the age of 1 day ( $24 \pm 6$ hours) and 5 days ( \pm 1 day). The glucose level was measured in whole blood. The parameters measured in the serum were: bilirubin, cholesterol, glutamic oxaloacetic transaminase (GOT, ET 2.6.1.1.), glutamic pyruvic transaminase (GPT, EC 2.6.1.2), total protein, albumins and alpha-, beta- and gammaglobulins. Routine methods were employed in the determination of these components.

The Harvey (1987) LSML program was used for statistical evaluation of the data. The model included fixed effects of parity (1, 2, 3 and beyond), periparturient disorders (normal delivery, placenta retention, dystocia, milk fever), year-month (five 3-month classes), sex, and ratio of Holstein-Friesian genes $(0-33 \%, 34-66 \%$, over $67 \%$ and beyond). Initially, the model also included all two-way interactions between parity and disorders. As those components appeared to be negligible and nonsignificant, they were deleted from the final calculations. The results of the statistical analysis are presented by the least squares means (LSM) and standard errors (SE).

In addition, the statistical evaluation of data also encompassed frequency analysis of mortality in calves within the period of 6 to 30 days following birth. The significance of differences was verified using the chi-square test. 
TABLE 1

Effects of parity on glucose, bilirubin, cholesterol, GOT and GPT concentrations in newborn calves

\begin{tabular}{|c|c|c|c|c|c|}
\hline \multirow{3}{*}{$\begin{array}{c}\text { Blood } \\
\text { components }\end{array}$} & \multirow{3}{*}{$\begin{array}{l}\text { No. of } \\
\text { parity }\end{array}$} & \multicolumn{4}{|c|}{ Age of calves (days) } \\
\hline & & \multicolumn{2}{|c|}{1} & \multicolumn{2}{|c|}{5} \\
\hline & & Mean & SE & Mean & SE \\
\hline Glucose & 1 & $4.54^{\mathrm{a}}$ & 0.28 & 4.49 & 0.19 \\
\hline \multirow[t]{2}{*}{$(\mathrm{mmol} / \mathrm{l})$} & 2 & $4.72^{\mathrm{A}}$ & 0.31 & 4.46 & 0.21 \\
\hline & $3 \geqslant$ & $4.06^{\mathrm{Aa}}$ & 0.24 & 4.30 & 0.17 \\
\hline Bilirubin & 1 & 32.1 & 3.4 & 22.1 & 2.1 \\
\hline \multirow[t]{2}{*}{$(\mu \mathrm{mol} / \mathrm{l})$} & 2 & 27.4 & 3.9 & 21.9 & 2.2 \\
\hline & $3 \geqslant$ & 32.1 & 3.2 & 20.0 & 1.9 \\
\hline Cholesterol & 1 & 1.29 & 0.09 & 2.15 & 0.12 \\
\hline \multirow[t]{2}{*}{$(\mathrm{mmol} / \mathrm{l})$} & 2 & $1.42^{\mathrm{a}}$ & 0.10 & 2.25 & 0.13 \\
\hline & $3 \geqslant$ & $1.25^{\mathrm{a}}$ & 0.08 & 2.18 & 0.11 \\
\hline GOT & 1 & 31.6 & 2.3 & 20.0 & 1.1 \\
\hline \multirow[t]{2}{*}{ (IU) } & 2 & 26.9 & 2.6 & 18.0 & 1.3 \\
\hline & $3 \geqslant$ & 28.3 & 2.1 & 17.8 & 1.0 \\
\hline GPT & 1 & 7.0 & 0.9 & 8.2 & 0.5 \\
\hline \multirow[t]{2}{*}{$/ \mathrm{IU} /$} & 2 & 6.8 & 0.9 & 6.7 & 0.6 \\
\hline & $3 \geqslant$ & 6.4 & 0.8 & 7.0 & 0.5 \\
\hline
\end{tabular}

Values in columns followed by identical letters are significantly different: capitals $-\mathrm{P} \leqslant 0.01$; lower case $-P \leqslant 0.05$

$\mathrm{SE}-$ Standard errors

Numbers of calves: $1-51$

$2-42$
$3 \geqslant-73$

\section{RESULTS}

The effects of parity on the analysed blood components are presented in Table 1 and 2. Parity had a significant effect on glucose and cholesterol levels measured on the first day of life. The highest level of these components was found in calves born by second parity cows, their lowest level was found in the group born by the oldest cows (third and later parities). The differences between these groups amounted to $0.66 \mathrm{mmol} / 1$ for glucose $(P \leqslant 0.01)$ and $0.17 \mathrm{mmol} / 1$ for cholesterol $(\mathrm{P} \leqslant 0.05)$. A significant difference was also found between calves born by the youngest and the oldest cows in respect to the glucose level $(0.48 \mathrm{mmol} / \mathrm{l}$; 
TABLE 2

Effects of parity on total protein, albumin, and alpha-, beta- and gammaglobulin concentrations in newborn calves $(\mathrm{g} / \mathrm{l})$

\begin{tabular}{|c|c|c|c|c|c|}
\hline \multirow{3}{*}{$\begin{array}{c}\text { Blood } \\
\text { components }\end{array}$} & \multirow{3}{*}{$\begin{array}{l}\text { No. of } \\
\text { parity }\end{array}$} & \multicolumn{4}{|c|}{ Age of calves (days) } \\
\hline & & \multicolumn{2}{|c|}{1} & \multicolumn{2}{|c|}{5} \\
\hline & & Mean & SE & Mean & SE \\
\hline \multirow[t]{3}{*}{ Total protein } & 1 & 57.8 & 3.0 & 69.5 & 2.4 \\
\hline & 2 & 61.9 & 3.6 & 69.4 & 2.7 \\
\hline & $3 \geqslant$ & 61.5 & 2.7 & 70.3 & 2.3 \\
\hline \multirow[t]{3}{*}{ Albumins } & 1 & 23.6 & 1.2 & 27.8 & 1.4 \\
\hline & 2 & 26.2 & 1.4 & 27.2 & 1.5 \\
\hline & $3 \geqslant$ & 25.1 & 1.1 & 27.3 & 1.2 \\
\hline \multirow[t]{3}{*}{ Alphaglobulins } & 1 & 18.8 & 0.9 & 20.9 & 1.0 \\
\hline & 2 & 19.9 & 1.0 & 21.5 & 1.1 \\
\hline & $3 \geqslant$ & 21.1 & 0.8 & 21.0 & 0.9 \\
\hline \multirow[t]{3}{*}{ Betaglobulins } & 1 & 7.8 & 1.0 & 12.8 & 0.8 \\
\hline & 2 & 8.1 & 1.2 & 13.1 & 0.9 \\
\hline & $3 \geqslant$ & 9.1 & 0.9 & 13.5 & 0.8 \\
\hline \multirow[t]{3}{*}{ Gammaglobulins } & 1 & 7.6 & 1.7 & 8.0 & 1.6 \\
\hline & 2 & 7.7 & 2.1 & 7.6 & 1.8 \\
\hline & $3 \geqslant$ & 6.2 & 1.6 & 8.5 & 1.5 \\
\hline
\end{tabular}

Explanations - see Table I

$P \leqslant 0.05$ ). Although nonsignificant, the inter-group differences at the age of 5 days tended to display the same pattern as on the first day of life.

The periparturient disorders had significant effects on the concentrations of glucose, total protein, beta- and gammaglobulins measured on the first day of life, and on the total protein concentration on the fifth day of life (Tables 3-4). When the cows with disorders were considered jointly (groups 2-4), the concentrations of the aforementioned variables were significantly lower than in calves deriving from normal deliveries $(P \leqslant 0.01)$.

On the first day of life, milk fever in the dam was associated with the largest decrease of the level of glucose $(1.48 \mathrm{mmol} / \mathrm{l} ; P \leqslant 0.01)$. At that age, other disorders also exerted a considerable, although nonsignificant, influence on decreasing the level of this metabolite. Table 3 contains noteworthy results showing that dystocia was associated with decreased cholesterol and increased GOT and GPT levels. Dystocia had the greatest depressing effect on total protein, albumin, beta- and gammaglobulin concentrations (Table 4). Compared 
TABLE 3

Effects of periparturient disorders on glucose, bilirubin, cholesterol, GOT and GPT concentrations in newborn calves

\begin{tabular}{|c|c|c|c|c|c|}
\hline \multirow{3}{*}{$\begin{array}{c}\text { Blood } \\
\text { components }\end{array}$} & \multirow{3}{*}{$\begin{array}{c}\text { Group of } \\
\text { dams }\end{array}$} & \multicolumn{4}{|c|}{ Age of calves (days) } \\
\hline & & \multicolumn{2}{|c|}{1} & \multicolumn{2}{|c|}{5} \\
\hline & & Mean & SE & Mean & SE \\
\hline Glucose & 1 & $4.92^{\mathrm{AB}}$ & 0.22 & 4.55 & 0.13 \\
\hline \multirow[t]{4}{*}{$(\mathrm{mmol} / 1)$} & 2 & 4.64 & 0.30 & 4.61 & 0.20 \\
\hline & 3 & 4.75 & 0.41 & 4.32 & 0.32 \\
\hline & 4 & $3.44^{\mathrm{A}}$ & 0.52 & 4.34 & 0.34 \\
\hline & $2-4$ & $4.47^{\mathrm{B}}$ & 0.28 & 4.51 & 0.18 \\
\hline Bilirubin & 1 & 29.1 & 2.7 & 20.7 & 1.5 \\
\hline \multirow[t]{4}{*}{$(\mu \mathrm{mol} / \mathrm{l})$} & 2 & 34.4 & 3.9 & 20.9 & 2.2 \\
\hline & 3 & 28.9 & 5.5 & 20.7 & 3.4 \\
\hline & 4 & 29.9 & 6.7 & 23.1 & 3.9 \\
\hline & $2-4$ & 32.3 & 3.5 & 21.2 & 2.0 \\
\hline Cholesterol & 1 & 1.38 & 0.07 & 2.34 & 0.09 \\
\hline \multirow[t]{4}{*}{$(\mathrm{mmol} / \mathrm{l})$} & 2 & 1.38 & 0.10 & 2.18 & 0.13 \\
\hline & 3 & 1.11 & 0.14 & 2.16 & 0.20 \\
\hline & 4 & 1.41 & 0.17 & 2.11 & 0.24 \\
\hline & $2-4$ & 1.32 & 0.09 & 2.16 & 0.13 \\
\hline GOT & 1 & 29.9 & 1.7 & 19.2 & 0.8 \\
\hline \multirow[t]{4}{*}{ (IU) } & 2 & 24.9 & 2.4 & 18.7 & 1.2 \\
\hline & 3 & 35.7 & 3.5 & 18.1 & 1.9 \\
\hline & 4 & 26.3 & 4.8 & 18.3 & 2.4 \\
\hline & $2-4$ & 27.5 & 2.1 & 18.5 & 1.1 \\
\hline GPT & 1 & 6.7 & 0.7 & 7.3 & 0.4 \\
\hline \multirow{4}{*}{ (IU) } & 2 & 5.8 & 0.9 & 7.4 & 0.6 \\
\hline & 3 & 8.7 & 1.1 & 6.2 & 1.1 \\
\hline & 4 & 5.6 & 1.5 & 8.3 & 1.1 \\
\hline & $2-4$ & 6.4 & 0.8 & 7.4 & 0.7 \\
\hline
\end{tabular}

Values in columns followed by identical letters are significantly different $-P \leqslant 0.01$

$\mathrm{SE}$ - Standard errors

1) 1 - Normal delivery $(n=127)$

2 - Placenta retention $(n=23)$

3 - Dystocia $(\mathrm{n}=9)$

$4-$ Milk fever $(n=7)$ 
TABLE 4

Effects of periparturient disorders in dams on total protein, albumin, and alpha-, beta- and gammaglobulin concentrations in newborn calves $(\mathrm{g} / \mathrm{l})$

\begin{tabular}{|c|c|c|c|c|c|}
\hline \multirow{3}{*}{$\begin{array}{c}\text { Blood } \\
\text { components }\end{array}$} & \multirow{3}{*}{$\begin{array}{l}\text { Group of } \\
\text { dams }\end{array}$} & \multicolumn{4}{|c|}{ Age of calves (days) } \\
\hline & & \multicolumn{2}{|c|}{1} & \multicolumn{2}{|c|}{5} \\
\hline & & Mean & SE & Mean & SE \\
\hline \multirow[t]{5}{*}{ Total protein } & 1 & $67.6^{\mathrm{ABa}}$ & 2.3 & $73.7 \mathrm{ABa}$ & 1.8 \\
\hline & 2 & $61.2^{a}$ & 3.4 & 73.6 & 2.7 \\
\hline & 3 & $52.7^{\mathrm{A}}$ & 4.3 & $64.3^{A}$ & 3.6 \\
\hline & 4 & 60.3 & 5.3 & $67.2^{\mathrm{a}}$ & 4.0 \\
\hline & $2-4$ & $58.6^{\mathrm{B}}$ & 3.0 & $69.9^{\mathrm{B}}$ & 2.4 \\
\hline \multirow[t]{5}{*}{ Albumins } & 1 & 26.2 & 1.0 & 27.4 & 1.0 \\
\hline & 2 & 24.5 & 1.4 & 29.8 & 1.5 \\
\hline & 3 & 22.4 & 1.7 & 25.1 & 2.0 \\
\hline & 4 & 26.9 & 2.1 & 27.4 & 2.2 \\
\hline & $2-4$ & 24.3 & 1.3 & 28.1 & 1.3 \\
\hline \multirow[t]{5}{*}{ Alphaglobulins } & 1 & 20.1 & 1.7 & 22.1 & 0.8 \\
\hline & 2 & 20.1 & 1.7 & 20.8 & 1.1 \\
\hline & 3 & 19.8 & 1.2 & 21.7 & 1.4 \\
\hline & 4 & 19.8 & 1.5 & 19.8 & 1.6 \\
\hline & $2-4$ & 20.0 & 1.0 & 20.9 & 1.0 \\
\hline \multirow[t]{5}{*}{ Betaglobulins } & 1 & $10.4^{\mathrm{Aab}}$ & 0.8 & 13.9 & 0.6 \\
\hline & 2 & 9.4 & 1.1 & 13.4 & 0.9 \\
\hline & 3 & $6.9^{\mathrm{a}}$ & 1.4 & 12.9 & 1.2 \\
\hline & 4 & $6.7^{b}$ & 1.7 & 12.2 & 1.3 \\
\hline & $2-4$ & $8.2^{\mathrm{A}}$ & 1.0 & 13.0 & 0.9 \\
\hline \multirow[t]{5}{*}{ Gammaglobulins } & 1 & $10.9^{\mathrm{AB}}$ & 1.4 & 10.3 & 1.2 \\
\hline & 2 & 7.2 & 2.0 & 9.6 & 1.8 \\
\hline & 3 & $3.6^{\mathrm{A}}$ & 2.5 & 4.5 & 2.3 \\
\hline & 4 & 6.9 & 3.0 & 7.8 & 2.6 \\
\hline & $2-4$ & $6.1^{\mathrm{B}}$ & 1.9 & 7.9 & 1.7 \\
\hline
\end{tabular}

Values in columns followed by identical letters are significantly different: capitals $-P \leqslant 0.01$; lower case $-\mathbf{P} \leqslant 0.05$

Other explanations - see Table 3

to the group of normal deliveries, on the first day of life the respective differences equalled $14.9 \mathrm{~g} / \mathrm{l}(\mathrm{P} \leqslant 0.01), 3.8 \mathrm{~g} / 1$ (nonsignificant), $3.5 \mathrm{~g} / \mathrm{l}(\mathrm{P} \leqslant 0.05)$ and $7.3 \mathrm{~g} / \mathrm{l}$ $(P \leqslant 0.01)$. In relation to this group significant differences were also found for total protein in the case of placenta retention $(6.4 \mathrm{~g} / 1 ; P \leqslant 0.05)$ and for betaglobulins in the case of milk fever $(3.7 \mathrm{~g} / \mathrm{l} ; \mathrm{P} \leqslant 0.05)$. 
At the age of 5 days, the inter-group differences observed on the first day of birth tended to be maintained for total protein, albumin and gammaglobulin concentrations (Table 4). This was particularly well visible in the dystocia group.

Mortality rates in calves between days 6 and 30 after birth amounted to $9.8 \%$ $(n=5)$ in the first parity, $7.1 \%(n=3)$ in the second parity and $23.3 \%(n=17)$ in the third and later parities. A significant difference appeared between the second and third groups $(P \leqslant 0.05)$. Mortality in calves grouped by the occurrence of periparturient disorders in their dams was $12.6 \%(\mathrm{n}=16)$ in the normal delivery group, $8.7 \%(\mathrm{n}=2)$ in the retained placenta group, $33.3 \%$ $(n=3)$ in the dystocia group and $57.1 \%(n=4)$ in the milk fever group. Significant differences were found between the normal delivery and retained placenta groups on the one hand, and the milk fever group on the other $(P \leqslant 0.01)$.

\section{DISCUSSION}

The relatively great health problems in bovine neonates, compared to other large farm animals, arise from two reasons. First, this species requires a particularly notable amount of assistance during parturition (Houwing et al., 1990). Second, calves are born almost agammaglobulinemic, and this type of immunity must be obtained via colostrum which is possible within roughly only the first 24 hour of life. Due to numerous cow, calf, management and environmental factors, the level of colostral immunity usually displays a large variation. The effects are particularly well visible in dairy calves nursed by their dams (Roy, 1990; Besser et al., 1991).

In investigations of other authors, the effects of parity on blood composition in newborn calves were analysed just in respect to the immunological traits (Edwards et al., 1992; Donowan et al., 1986). The former authors found that calves deriving from the second delivery had the highest levels of colostral immunoglobulins, whereas the latter reported that the age of the dam had a systematically decreasing effect of the level of total protein. Thus, the results of the present study do not confirm either of those findings.

The results of the biochemical analyses presented in Table 1 indicate that the biologically most vital were calves born to second parity cows. Namely, this group revealed the highest levels of glucose and cholesterol. A high level of glucose in the one-day-old calves is evidence of proper acid-base balance and respiratory functions, which in turn account for the fast adaptation of the newborn to the external environment (Kasari, 1989; Vermorel et al., 1989). According to Kurz and Willet (1991), the levels of glucose and cholesterol in calves of that age are associated with the time elapsed between birth and the first ingestion of colostrum. Also in the earlier work of this author (Skrzypek, 1985), 
it was proved that these metabolites measured in calves aged 24 hours were firmly associated with their survival. In the present investigation the weakest calves seem to have been born from the oldest cows, since the lowest concentrations of glucose and cholesterol were found in them. The conclusions about the significant effects of parity on the vitality of calves, based on analysis of the behaviour of diagnostic parameters, appear to be supported by direct analysis of mortality in the neonatal period, for the lowest mortality rate was found in the second parity group of calves, whilst the highest was in the group born by the oldest cows.

The effects of the periparturient disorders on the diagnostic parameters in calves were determined for dystocia only. Eigenmann et al. (1983) and Donovan et al. (1986) found that this disorder had a detrimental effect on the level of passive immunity, decreasing the sucking activity. Kasari (1989) and Vermorel at al. (1989) determined that dystocia lowered the concentrations of glucose and NEFA. Although the latter were not investigated in the present work, it has been widely accepted that this group of metabolites exhibits a close, positive correlation with the level of cholesterol. The above mentioned findings of other authors seem to be extensively supported by the results of the present study, which is particularly visible in the cases of all of the studied immunological parameters and cholesterol.

The remaining two groups of cows with periparturient disorders gave birth to calves which also revealed unfavourable deviations in blood composition. The immunological status of both groups of calves seemed to be similar, and slightly lower than that in the group from normal deliveries, whereas the group with milk fever definitely had the lowest level of glucose on the first day of birth.

Direct analysis of calf mortality showed that the calves born by cows exhibiting symptoms of dystocia and milk fever died much more frequently within their first month after birth, than calves deriving from the remaining two groups of dams.

\section{CONCLUSIONS}

Results of this study suggest that the parity and the periparturient disorders in cows play an important role in formation of the metabolic and immunological status of the newborn calf, and thereby affect the rate of mortality within the neonatal period.

Calves born from second parity cows displayed the best values of diagnostic parameters, whereas these parameters in calves born in the third or later parities were the least advantageous.

Dystocia and milk fever had markedly detrimental effects on the biochemical and immunological status of the newborn calf. 


\section{ACKNOWLEDGEMENTS}

The author wishes to thank Mr. Wiesław Jarmuż for sampling calves and field observations, and Mr. Piotr Ślósarz for his very valuable help in computation of data.

\section{REFERENCES}

Besser T. E., Gay C. C., Pritchett L., 1991. Comparison of three methods of feeding colostrum to dairy calves. J. Amer. Vet. Med. Assn. 198, 419-422

Chmielnik H., Sawa A., 1988. Przyczyny śmiertelności okołoporodowej u cieląt. Zesz. probl. Post. Nauk rol. 333, 135-145

Donovan G. A., Badinga L., Collier R. J., Wilcox C. J., Braun R. K., 1986. Factors influencing passive transfer in dairy calves. J. Dairy Sci. 69, 754-759

Edwards S. A., Broom D. M., Collis S. C., 1982. Factors affecting levels of passive immunity in dairy calves. Br. Vet. J. 138, 233-240

Eigenmann U. J. E., Zaremba W., Leutgebrune K., Grunert E., 1983. Untersuchungen über die Kolostrumaufnahme und die Immunoglobulinabsorption bei Kälbern mit und ohne Geburtsazidose. Berl. Mün. Tierärztl. Wochenschr. 96, 109-113

Harvey W. R., 1987. Mixed model least-squares and maximum likelihood computer program. Ohio State University, Columbus, $\mathrm{OH}, \mathrm{pp} .59$

Houwing H., Hurnik J. F., Lewis N. J., 1990. Behaviour of periparturient dairy cows and their calves. Can. J. Anim. Sci. 70, 355-362

Kasari T. R., 1989. Weakness in neonatal calves associated with dystocia. Agri-Practice 10, 19-25

Kurz M. M., Willet L. B., 1991. Carbohydrate, enzyme, and hematology dynamics in newborn calves. J. Dairy Sci. 74, 2109-2118

Roy J. H. B., 1990. The calf. I. Management and health. V edition, pp. 1-52

Skrzypek R., 1985. Zastosowanie wybranych wskażników biochemicznych krwi do przewidywania użytkowości mlecznej i rozrodczej krów oraz zdrowotności i przeżywalności cieląt. Rocz. AR Pozn., Rozpr. Nauk. 143, pp. 28

Skrzypek R., Jarmuż W., Szuba-Jabłoński I., Zależności między zaburzeniami okresu okoloporodowego a użytkowością i brakowaniem krów oraz śmiertelnością cieląt. Rocz. AR Pozn. (in print).

Vermorel M., Vernet J., Dardillat C., Saido, Demigne C., Davicco M. - J., 1989. Energy metabolism and thermoregulation in the newborn calf; effect of calving conditions. Can. J. Anim. Sci. 69 , $113-122$

Żarnecki A., Mrowiec S., Dworak D., Jamrozik J., 1988. Trudne porody i śmiertelność cieląt u bydła czarno-bialego i czerwono-białego. Zesz. probl. Post. Nauk rol. 233, 179--184

\section{STRESZCZENIE}

\section{Wpływ kolejności wycielenia i zaburzeń okresu okołoporodowego u krów na wskaźniki biochemiczne} i immunologiczne urodzonych cieląt

Badania przeprowadzono na 166 pojedynczo urodzonych cielętach rasy nizinnej czarno-białej i mieszańcach $z$ Holsztyno-Fryzami. U cieląt w wieku 1 dnia ( 24 godziny \pm 6 ) i 5 dni ( \pm 1 ) oznaczano we krwi następujące składniki: glukozę, bilirubinę, cholesterol, GOT, GPT, białko całkowite, albuminy oraz alfa-, beta- $i$ gammaglobuliny.

Analiza statystyczna danych wykazala, że kolejność wycielenia oraz zaburzenia okresu okoloporodowego u krów mialy istotny wpływ na sklad krwi i śmiertelność cieląt. Cielęta pochodzące od krów cielących się po raz drugi miały najlepszy sklad krwi, a mianowicie najwyźszy poziom glukozy i cholesterolu. U cieląt urodzonych przez krowy starsze zawartość tych składników była najniższa. 
Poziom glukozy, białka całkowitego, beta- i gammaglobulin we krwi u cieląt pochodzących od krów z zaburzeniami okresu okołoporodowego był obniżony. Trudne wycielenia i zaleganie poporodowe miały najbardziej negatywny wpływ na status biochemiczny $\mathrm{i}$ immunologiczny cieląt.

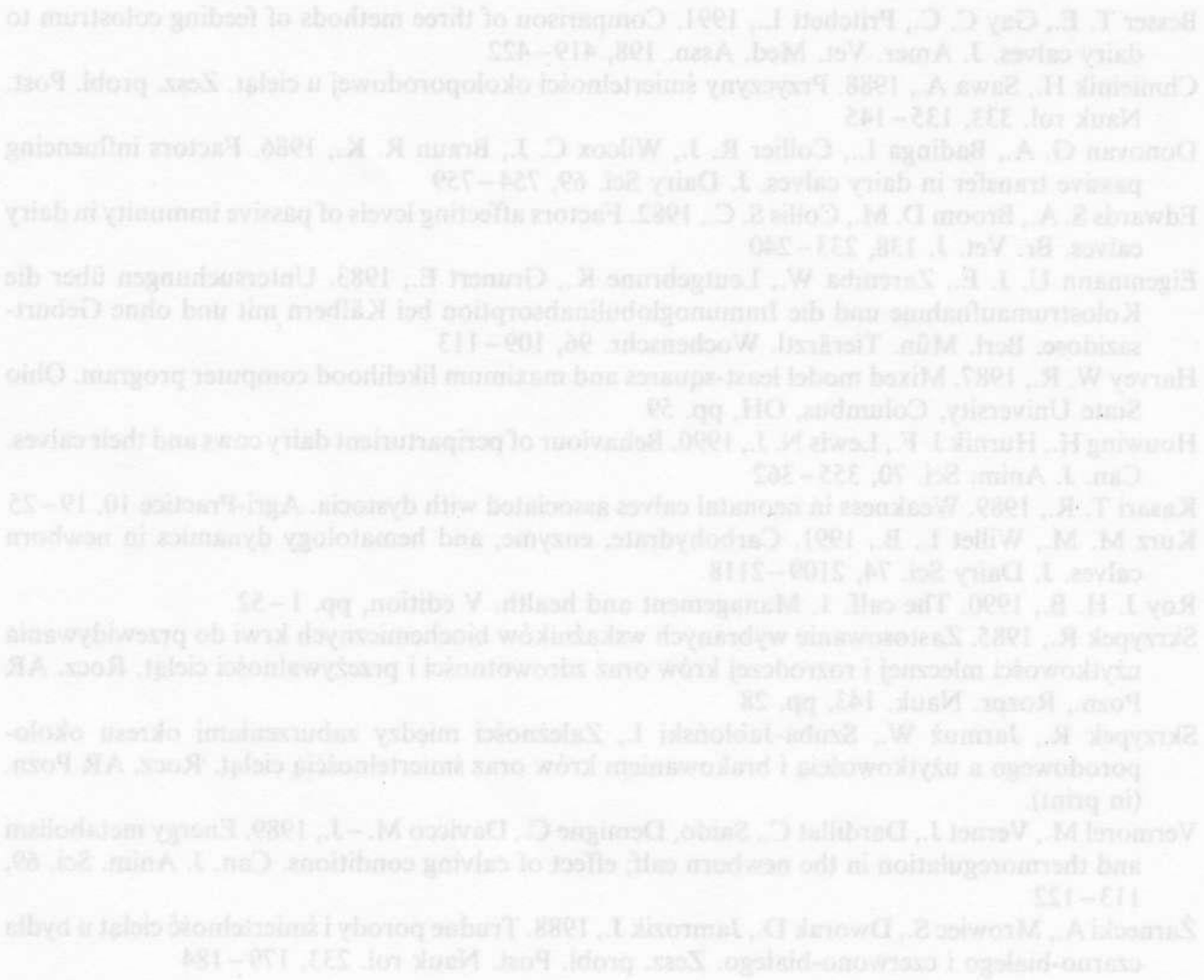

